\title{
Involvement of J AK2 and MAPK on type II nitric oxide synthase expression in skin-derived dendritic cells
}

\author{
M. T. CRUZ, ${ }^{1,2}$ C. B. DUARTE, ${ }^{2}$ M. GONÇALO, ${ }^{3}$ A. P. CARVALHO, ${ }^{2}$ AND M. C. LOPES ${ }^{1,2}$ \\ ${ }^{1}$ Faculdade de Farmácia e ${ }^{3} \mathrm{~F}$ acul dade de Medicina (Servico de Dermatologia), ${ }^{2}$ Centro de \\ Neurociências, Universidade de Coimbra, 3000 Coimbra, Portugal
}

\begin{abstract}
Cruz, M. T., C. B. Duarte, M. Gonçalo, A. P. Carvalho, and M. C. Lopes. I nvolvement of J AK2 and MAPK on typell nitric oxide synthase expression in skin-derived dendritic cells. Am. J . Physiol. 277 (Cell Physiol. 46): C1050-C1057, 1999.-In this report, we demonstrate that a fetal mouse skin-derived dendritic cell line produces nitric oxide (NO) in response to the endotoxin [lipopolysaccharide (LPS)] and to cytokines [tumor necrosis factor- $\alpha(T N F-\alpha)$ and granulocytemacrophage colony-stimulating factor (GM-CSF)]. Expression of the inducible isoform of NO synthase (iNOS) was confirmed by immunofluorescence with an antibody against iNOS. Thetyrosine kinase inhibitor genistein decreased LPSand GM-CSF-induced nitrite $\left(\mathrm{NO}_{2}^{-}\right)$production. The effect of LPS and cytokines on $\mathrm{NO}_{2}^{-}$production was inhibited by the J anus kinase 2 (J AK2) inhibitor tyrphostin B42. The p38 mitogen-activated protein kinase (p38 MAPK) inhibitor SB203580 also reduced the $\mathrm{NO}_{2}^{-}$production evoked by LPS, TNF- $\alpha$, or GM-CSF, but it was not as effective as tyrphostin B42. I nhibition of MAPK kinase with PD-098059 al so slightly reduced the effect of TNF- $\alpha$ or GM-CSF on $\mathrm{NO}_{2}^{-}$production. I mmunocytochemistry studies revealed that the transcription factor nuclear factor- $\mathrm{B}$ was translocated from the cytoplasm into the nudei of fetal skin-derived dendritic cells (FSDC) stimulated with LPS, and this translocation was inhibited by tyrphostin B42. Our results show that J AK2 plays a major rolein the induction of iNOS in FSDC.
\end{abstract}

mitogen-activated protein kinase; J anus kinase 2; nuclear factor-кB

NITRIC OXIDE (NO) is generated by the enzyme nitric oxide synthase (NOS), of which three related, but functionally distinct, isoforms have been identified in mammalian cells. Type I and type III NOS are constitutively expressed in cells of neural and endothelial origin, respectively, and they are regulated by physiol ogical changes in the intracellular cal cium concentration. In contrast, type II NOS (or iNOS) is expressed in cells with immunoregulatory functions in response to a wide array of proinflammatory cytokines and bacterial cell wall products (16).

Because skin is the first defense against a hostile environment, NO produced by Langerhans cells (LC), keratinocytes, and/or dermal dendritic cells (DC) may have an important contribution to host defense against skin pathogens. In addition, several reports are consistent with NO being involved in skin inflammatory diseases (5) and in the modulation (enhancement or suppression) of antigen presentation (20).

\footnotetext{
The costs of publication of this article were defrayed in part by the payment of page charges. The article must therefore be hereby marked "advertisement" in accordance with 18 U.S.C. Section 1734
} solely to indicate this fact.
The cellular and molecular mechanisms involved in the control of NO synthesis are a subject of the current investigation. The intracellular signals that regulate the expression of iNOS have been studied in different cell types, and, although it has not been fully characterized yet, iNOS expression appears to be regulated in a cell-specific manner. Protein kinase C (PKC), protein tyrosine kinases (PTKs), and CAMP-dependent protein kinase have been found to be involved in the regulation of iNOS expression $(14,17,19,23,28-30)$. Activation of some of these kinases may stimulate the mitogenactivated protein kinases (MAPK), a family of structurally related kinases that are involved in cellular events, such as growth, differentiation, and stress responses (25). In mammalian cells, three subgroups of MAPK have been detected and include the extracel lular signalregulated kinases (ERKs, p42/p44), the c-J un aminoterminal kinases (J NKs), and the p38 MAPKs (25). Cytokines activate members of the MAPK and of the J anus kinase (J AK) families of PTKs which, in turn, activate by phosphorylation one or more transcription factors that are translocated from the cytoplasm to the nucleus to induce gene transcription $(13,25)$.

The signaling events required for $\mathrm{NO}$ production in DC have not been identified yet. Studies on LC (and DC) have been hampered by the difficulties in obtaining large amounts of LC devoid of contaminating cells. In our study, we circumvented this problem by using a mouse fetal skin dendritic cell line (FSDC) that is representative of early DC precursors (10). We studied the effect of lipopolysaccharide (LPS) and cytokines [granulocyte-macrophage colony-stimulating factor (GM-CSF), interleukin-1 $(\mathrm{IL}-1 \beta)$, and tumor necrosis factor $-\alpha(T N F-\alpha)$ ] on the production of NO by F SDC and the role played by genistein-sensitive tyrosine kinases and by the MAPK and JAK pathways in the process. Furthermore, we investigated the effect of LPS and cytokines on the intracellular distribution of the nuclear

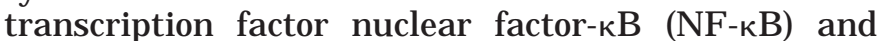
whether J AK 2 is involved in NF - $\mathrm{BB}$ activation.

\section{MATERIALS AND METHODS}

Materials. The rabbit anti-mouse iNOS polyclonal antibody was purchased from Transduction Laboratories (Lexington, KY), the rabbit anti-human NF-kB p65 was from Serotec (Oxford, UK), and the fluorescein isothiocyanate (FITC)conjugated swineanti-rabbit immunogl obulin was from DAKO (Copenhagen, Denmark). The Prolong Antifade Kit was obtained from Molecular Probes Europe (Leiden, The Netherlands). LPS from Escherichia coli (serotype 026:B6) was obtained from Sigma Chemical (St. Louis, MO), the mouse TNF - $\alpha$ receptor was from Boehringer Mannheim (Carnaxide, Portugal), and mouse IL-1 $\beta$ receptor was purchased from Pharmingen (San Diego, CA). The murine GM-CSF receptor 
was from Serotec; SB-203580 was a kind gift of Dr. J. L. Adams from SmithKline Beecham Pharmaceuticals (King of Prussia, PA). Tyrphostin B42 and PD-098059 were obtained from RBI (Natick, MA), FCS was from Biochrom (Berlin, Germany), and trypsin was from GIBCO (Paisley, UK). Genistein and genistin were from Sigma Chemical. All other reagents were from Sigma Chemical.

Cell culture The fetal mouse skin dendritic cell line FSDC was kindly supplied by Dr. G. Girolomoni (10). This cell line was generated from fetal mouse skin by infecting a cell suspension with a retroviral vector carrying an envAKR myc ${ }^{\mathrm{MH} 2}$ fusion gene. FSDC show characteristics of immature DC and express low levels of major hisotcompatibility complex II molecules (I-A $\left.{ }^{d, b}\right)$, and their proliferation in serumfree medium occurs in the presence of GM-CSF, but not macrophage colony-stimulating factor, indicating that they are dendritic cell precursors (10).

The cells were cultured in I scove's medium supplemented with $10 \%$ FCS, $1 \%$ glutamine, $100 \mu \mathrm{g} / \mathrm{ml}$ streptomycin, and $100 \mathrm{U} / \mathrm{ml}$ penicillin.

Cell viability. Assessment of cell viability was made in all experimental conditions by a colorimetric assay using 3-(4,5dimethylthiazol-2-yl)-2,5-di phenyl-tetrazolium bromide(MTT; see Ref. 24). After removal of cell-free supernatants for the nitrite $\left(\mathrm{NO}_{2}^{-}\right)$assay, $400 \mu \mathrm{l}$ of culture medium and $40 \mu \mathrm{l}$ of MTT solution ( $5 \mathrm{mg} / \mathrm{ml}$ in PBS) were added to each well. The microplates were further incubated at $37^{\circ} \mathrm{C}$ for $1 \mathrm{~h}$. Supernatants were then discarded, and $300 \mu$ of acidified isopropanol $(0.04 \mathrm{~N} \mathrm{HCl}$ in isopropanol) were added to the cultures and mixed thoroughly to dissolve the dark blue crystals of formazan. The blank assay (no cells) was subtracted from the other readings. Formazan quantification was performed using an automatic plate reader (SLT) at $570 \mathrm{~nm}$, with a reference wavelength of $620 \mathrm{~nm}$.

$\mathrm{NO}_{2}^{-}$measurement. The production of $\mathrm{NO}$ was assessed as the accumulation of $\mathrm{NO}_{2}^{-}$in the culture supernatants, using a colorimetric reaction with the Griess reagent (11). Briefly, after stimulation for $48 \mathrm{~h}$, the culture supernatants were collected and mixed with equal volumes of the Griess reagent [0.1\% N-(1-naphthyl)ethylenediamine dihydrochloride, $1 \%$ sulfanilamide, and $\left.5 \% \mathrm{H}_{3} \mathrm{PO}_{4}\right]$, during $10 \mathrm{~min}$. The absorbance at $550 \mathrm{~nm}$ was measured in an automated plate reader (SLT). The $\mathrm{NO}_{2}^{-}$concentration was determined from a sodium nitrite standard curve.

Immunofluorescence microscopy. For immunofluorescence analysis, FSDC were grown on glass coverslips and were fixed and permeabilized by immersing the coverslips in $-20^{\circ} \mathrm{C}$ methanol-acetone (1:1) for 10 min. Nonspecific binding was blocked by incubation in PBS supplemented with normal swine serum (1:20) and $0.5 \%$ BSA for $45 \mathrm{~min}$ at room temperature. Cells were then incubated for $90 \mathrm{~min}$ at room temperature with a rabbit polyclonal anti body directed against mouse iNOS $(5 \mu \mathrm{g} / \mathrm{ml})$ or for $2 \mathrm{~h}$ with the rabbit polyclonal antibody directed against human p65 (1:200). After being rinsed with PBS, the cells were incubated with FITCconjugated swine anti-rabbit immunoglobulin (1:40 dilution) in $0.5 \%$ BSA-PBS for $45 \mathrm{~min}$. The coverslips were rinsed again as before and were mounted with a Prolong Antifade Kit on a slide. Cells labeled with FITC-anti-iNOS were photographed on a Nikon Diaphot-TMD microscope. The intracellular localization of FITC-labeled p65 was observed using the 488-nm line of a krypton/argon laser on a Bio-Rad MRC 600 fluorescent confocal microscope. Control experiments consisted of processing the same preparations as described, except for the omission of the primary antibody, and resulted in no specific staining.

Data analysis. Results are presented as means \pm SE of the indicated number of experiments. Mean values were compared using one-way ANOVA and the Bonferroni multiple comparison test. The significance level was 0.05 .

\section{RESULTS}

$\mathrm{NO}_{2}^{-}$production by FSDC response to LPS and cytokines. To determine whether NO production was inducible in FSDC, the mouse dendritic cell line in culture was treated with LPS or cytokines (GM-CSF, TNF- $\alpha$, and IL-1 $\beta$ ) for $48 \mathrm{~h}$, and the culture supernatants were collected for the $\mathrm{NO}_{2}^{-}$measurement (Fig. 1). Cell-free supernatants, from cells incubated in the presence of LPS $(5 \mu \mathrm{g} / \mathrm{ml})$, showed an increase in $\mathrm{NO}_{2}^{-}$ concentration (from $0.63 \pm 0.06$ to $24.1 \pm 2.92 \mu \mathrm{M}$ ), reflecting an increase in $\mathrm{NO}$ production. $\mathrm{NO}_{2}^{-}$production was also stimulated upon incubation of F SDC with $100 \mathrm{U} / \mathrm{ml}$ TNF $-\alpha$ (from $0.63 \pm 0.06$ to $4.76 \pm 0.82 \mu \mathrm{M})$ or $200 \mathrm{ng} / \mathrm{ml} \mathrm{GM}-\mathrm{CSF}$ (from $0.63 \pm 0.06$ to $6.32 \pm 1.1 \mu \mathrm{M}$ ). At a concentration of $200 \mathrm{ng} / \mathrm{ml}$, GM-CSF also caused a significant increase in the ability of FSDC to stimulate the allogeneic or syngeneic $\mathrm{T}$ cells in the primary mixed-leukocyte reaction (10). No significant NO production was observed in FSDC cultures exposed to I L-1ß (Fig. 1).

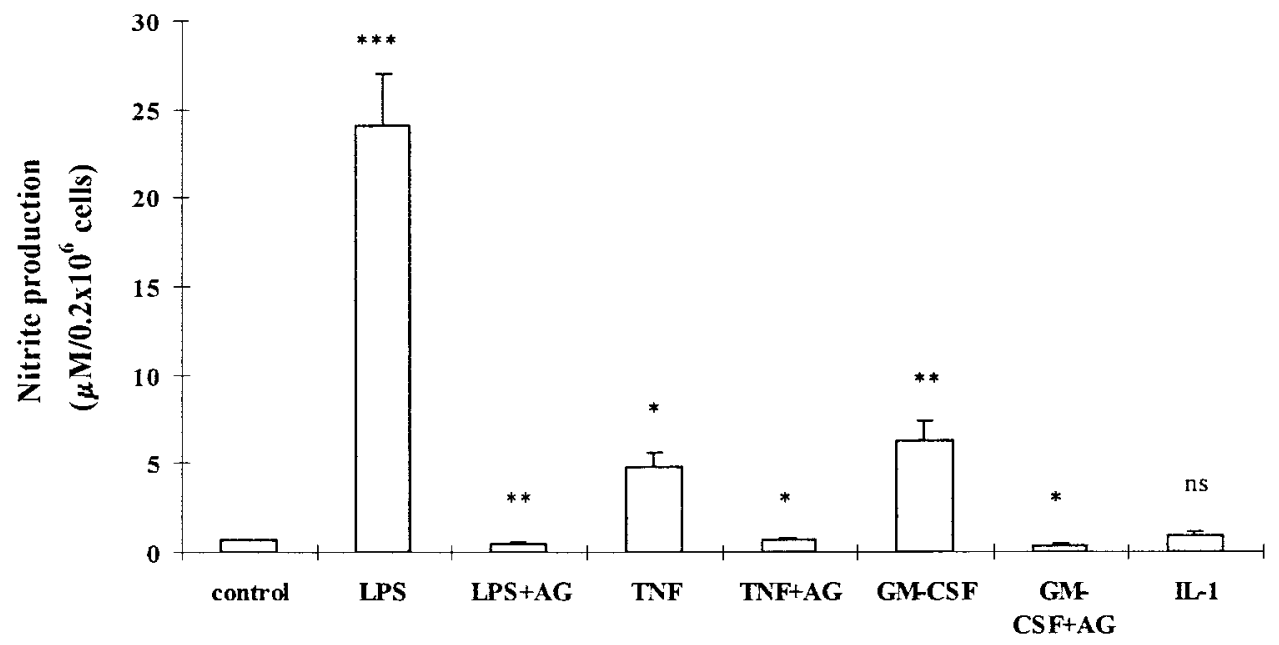

Fig. 1. Nitrite concentration in supernatants of nonstimulated fetal skin dendritic cells (FSDC) maintained in culture medium (control) or in cells stimulated for $48 \mathrm{~h}$ with $5 \mu \mathrm{g} / \mathrm{ml}$ lipopolysaccharide (LPS) or cytokines [100 $\mathrm{U} / \mathrm{ml}$ tumor necrosis factor- $\alpha$ (TNF- $\alpha$ ), $10 \mathrm{ng} / \mathrm{ml}$ interleukin-1 $(\mathrm{IL}-1 \beta)$, or 200 $\mathrm{ng} / \mathrm{ml}$ granulocyte-macrophage col onystimulating factor (GM-CSF)]. Cells were also incubated with aminoguanidine (AG; $1 \mathrm{mM}$ ) during the period of stimulation with the cytokines or LPS. Each value represents the mean $\pm \mathrm{SE}$ from 3-24 experiments, performed in duplicate. $* \mathrm{P}<0.05, * * \mathrm{P}<0.01, * * * \mathrm{P}<$ 0.001 , and ns, not significant. 
To confirm whether $\mathrm{NO}_{2}^{-}$was formed via the induction of iNOS, the cells were incubated for $48 \mathrm{~h}$ in the presence of the NOS inhibitor aminoguanidine (1 mM; see Ref. 37), which was added simultaneously with the cytokines or LPS. Aminoguanidine completely inhibited $\mathrm{NO}_{2}^{-}$accumulation in the culture supernatant induced either by LPS or by the cytokines TNF $-\alpha$ and GM-CSF (Fig. 1).

Because TNF- $\alpha$ may be involved in the activation of cytotoxic events (34) and considering that stimulation of macrophages with LPS plus interferon- $\gamma$ (IFN- $\gamma$ ) produces cytotoxic amounts of $\mathrm{NO}_{2}^{-}(21)$, which cause apoptosis (32), we evaluated the effects of LPS and cytokines on the viability of FSDC, using the MTT assay (Table 1). The results show that neither LPS nor cytokines significantly affected the FSDC viability (Table 1).

Identification of iNOS expression in FSDC line by immunocytochemistry. I mmunofluorescent labeling of FSDC with the anti-iNOS polyclonal antibody was markedly increased in cells stimulated with LPS (Fig. 2B) and GM-CSF (Fig. 2C) compared with the cells maintained in culture medium (Fig. 2A). Approximately $15-18 \%$ and $10-13 \%$ of the LPS- and GM-CSF stimulated cells, respectively, were iNOS positive. The number of cells expressing iNOS in the TNF- $\alpha$-treated cells and in the cells maintained in culture medium was 5-8 and 3-5\%, respectively (data not shown). These results indicated that FSDC expressed iNOS, which was inducible by LPS, GM-CSF, and TNF - $\alpha$.

Effect of protein kinase inhibitors on NO production by stimulated FSDC. To investigate the role of tyrosine kinases on the expression of iNOS induced by LPS and cytokines in FSDC, we studied the effect of genistein, a broad-spectrum inhibitor of tyrosine kinases (1), on the $\mathrm{NO}_{2}^{-}$production upon stimulation of the cells with LPS, TNF $-\alpha$, or GM-CSF. The genistein $(30 \mu \mathrm{M})$ slightly reduced $\mathrm{NO}_{2}^{-}$production induced by TNF- $\alpha(100 \mathrm{U} / \mathrm{ml})$ to $92.8 \pm 6.6 \%$, whereas $\mathrm{NO}_{2}^{-}$production induced by LPS $(5 \mu \mathrm{g} / \mathrm{ml})$ and by GM-CSF $(200 \mathrm{ng} / \mathrm{ml})$ was reduced to $24.6 \pm 5.5$ and $56.1 \pm 13.3 \%$ of the control, respectively (Table 2). Genistin, the inactive analog of genis-

Table 1. Effect of LPS and cytokines on the MTT reduction by FSDC

\begin{tabular}{cc}
\hline \hline & $\begin{array}{c}\text { MTT Reduction, } \\
\% \text { Control }\end{array}$ \\
\hline GM-CSF $(200 \mathrm{ng} / \mathrm{ml})$ & $99.1 \pm 5.7^{*}$ \\
& $(\mathrm{n}=19)$ \\
$\operatorname{LPS}(5 \mu \mathrm{g} / \mathrm{ml})$ & $88.3 \pm 2.6^{*}$ \\
& $(\mathrm{n}=20)$ \\
$\mathrm{TNF}-\alpha(100 \mathrm{U} / \mathrm{ml})$ & $95.1 \pm 3.2^{*}$ \\
& $(\mathrm{n}=19)$ \\
\hline
\end{tabular}

Values are means $\pm \mathrm{SE}$; no. of experiments performed in duplicate in parentheses. Fetal skin dendritic cells (FSDC) were incubated with lipopolysaccharide (LPS), tumor necrosis factor- $\alpha$ (TNF- $\alpha$ ), or granulocyte-macrophage colony-stimulating factor (GM-CSF) at the indicated concentration for $48 \mathrm{~h}$. The 3-(4,5-dimethylthiazol-2-yl)-2,5diphenyl-tetrazolium bromide (MTT) assay was performed as de scribed in MATERIALS AND METHODS. Results are expressed as a percentage of MTT reduction by control cells maintained in culture medium. ${ }^{*}$ Not significant. tein (1), did not affect $\mathrm{NO}_{2}^{-}$production evoked by LPS, TNF- $\alpha$, or by GM-CSF in FSDC (Table 2). Therefore, the significant effect of genistein on NO production induced by LPS and GM-CSF can be attributed to its ability to inhibit PTKs rather than to nonspecific effects.

We next investigated the role of MAPK kinase (MEK), p38 MAPK, and J AK2 in the activation of $\mathrm{NO}_{2}^{-}$production by LPS and cytokines in FSDC. The PD-098059 was used to inhibit the MEK activation (8), and the p38 MAPK and J AK2 were inhibited with SB-203580 (36) and tyrphostin B42 (22), respectively. The concentrations of genistein $(30 \mu \mathrm{M})$, PD-098059 $(30 \mu \mathrm{M})$, SB$203580(10$ and $20 \mu \mathrm{M})$, and tyrphostin B42 (20 $\mu \mathrm{M})$ were chosen based on the previously published studies $(8,14,22,36)$, and the assay of cellular MTT reduction in the presence of the indicated concentrations of the compounds revealed the lack of a significant toxic effect (data not shown).

The inhibitor PD-098059 was without effect on LPS-stimulated $\mathrm{NO}_{2}^{-}$production, which indicates that the MEK signaling cascade was not involved in the LPS-induced NO production in this cell line. In contrast, $\mathrm{NO}_{2}^{-}$production induced by either GM-CSF or TNF $-\alpha$ was slightly reduced, to $89.5 \pm 6.1$ and $83.2 \pm$ $4.4 \%$ of the control, respectively (Table 2 ), in the presence of $30 \mu \mathrm{M}$ PD-098059, a concentration of the antagonist that fully inactivates the MEK pathway (8).

The NO production, $48 \mathrm{~h}$ after LPS and cytokine stimulation, was only partially affected by the treatment with $20 \mu \mathrm{M}$ SB-203580. The p38 MAPK inhibitor reduced LPS-, GM-CSF-, and TNF- $\alpha$-induced $\mathrm{NO}_{2}^{-}$production to $78.8 \pm 3.6,72.4 \pm 7.0$ and $85.3 \pm 3.4 \%$ of the control, respectively. However, at the concentration of $20 \mu \mathrm{M}$, SB-203580 inhibited the MTT reduction by FSDC incubated simultaneously with this inhibitor and LPS by $\sim 86.3 \pm 2.9 \%$ of the control $(P<0.05$; data not shown). Under these experimental conditions, no morphological evidence of cell death was observed.

Tyrphostin B42 was a potent inhibitor of LPS-, GM-CSF- and TNF- $\alpha$-induced NO production in FSDC (Table 2), which indicates that the J AK pathway plays an important role in the regulation of iNOS expression. This compound was the most effective protein kinase inhibitor in preventing the cytokine-induced NO production; at $20 \mu \mathrm{M}$, tyrphostin $\mathrm{B} 42$ inhibited $\mathrm{NO}_{2}^{-}$production induced by TNF- $\alpha$ and by GM-CSF to $48.6 \pm 13.1$ and $38.2 \pm 7.5 \%$ of the control, respectively. The J AK2 inhibitor reduced $\mathrm{NO}_{2}^{-}$formation induced by LPS to $41.9 \pm 7.9 \%$ of the control. Although the J AK pathway plays an important role in the regulation of iNOS induction by LPS and cytokines, a role for p38 MAPK and MEK must also be considered in the control of iNOS expression in FSDC, since the simultaneous utilization of the inhibitors SB-203580 and PD-098059 reduced $\mathrm{NO}_{2}^{-}$formation evoked by LPS, TNF- $\alpha$, and GM-CSF to $76.3 \pm 5.8,62.6 \pm 1.05$ and $69.5 \pm 3.2 \%$ of the control, respectively (Table 2).

Translocation of NF $-\kappa \mathrm{B}$ in nuclei of theFSDC. In this set of experiments, we investigated the effect of LPS and cytokines on the intracellular distribution of the 

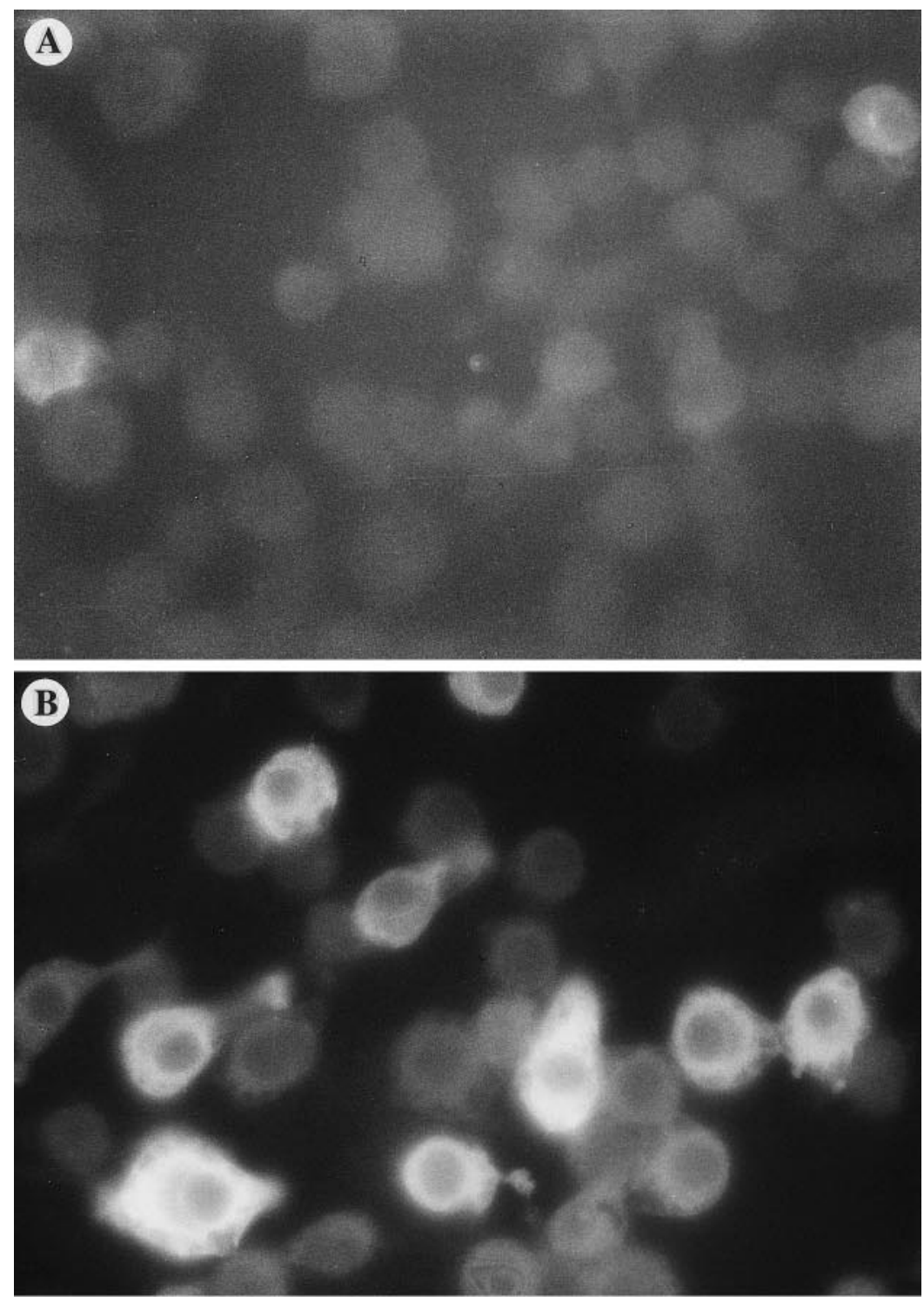

Fig. 2. Detection of inducible nitric oxide synthase (iNOS) protein expression in the FSDC line maintained for $48 \mathrm{~h}$ in culture medium, in the absence (A) or in the presence of $5 \mu \mathrm{g} / \mathrm{ml}$ LPS (B) or $200 \mathrm{ng} / \mathrm{ml} \mathrm{GM}-\mathrm{CSF}$ (C). I mmunostaining was performed as described in MATERIALS AND METHODS (magnification $\times 250$ ). Cells present in 8 fields in 2 preparations were counted.

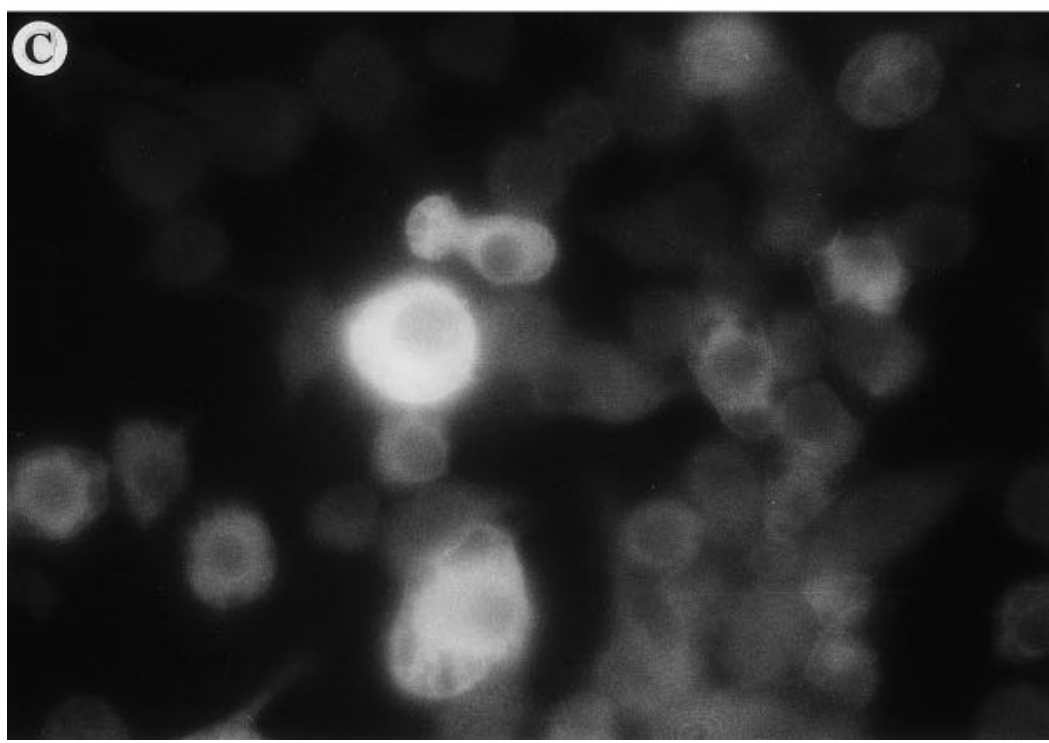


Table 2. Effect of different kinaseinhibitors and of genistin on LPS and cytokine-induced $\mathrm{NO}_{2}^{-}$production by F SDC

\begin{tabular}{|c|c|c|c|c|c|c|c|}
\hline & \multicolumn{7}{|c|}{ Nitrite Production, \% } \\
\hline LPS $(5 \mu \mathrm{g} / \mathrm{ml})$ & $24.6 \pm 5.5 \ddagger$ & $91.2 \pm 1.1 \S$ & $103.4 \pm 13.5 \S$ & $84.7 \pm 2.3 \dagger$ & $\begin{array}{c}78.8 \pm 3.6 \neq \\
\text { (5) }\end{array}$ & $76.3 \pm 5.8 \ddagger$ & $41.9 \pm 7.9 \ddagger$ \\
\hline
\end{tabular}

Values are means $\pm \mathrm{SE}$; no. of experiments performed in duplicate in parentheses. FSDC were incubated with the inhibitors at the indicated concentrations in the presence of LPS, TNF- $\alpha$, or GM-CSF for $48 \mathrm{~h} . \mathrm{NO}_{2}^{-}$levels in the culture supernatants were analyzed by the Griess reaction, as described in MATERIALS AND METHODS. Results are expressed as percentage of maximal $\mathrm{NO}_{2}^{-}$production by cells maintained in culture medium in the presence of LPS or cytokines and in the absence of inhibitors. $* P<0.05, \uparrow P<0.01, \ddagger P<0.001$, and $\S$ not significant.

nuclear transcription factor NF-kB and whether the observed effects could be attributed to $A K 2$.

The effect of LPS, GM-CSF, and TNF- $\alpha$ on the intracellular distribution of NF-кB in FSDC was examined immunocytochemically, using a specific antibody against the p65 subunit. Before LPS stimulation, p65 was distributed throughout the cytoplasm (Fig. 3A). When FSDC were treated with LPS for $30 \mathrm{~min}$, p65 was detected in most of the nuclei of FSDC ( $F$ ig. $3 B$ ), and this translocation was inhibited by inhibition of J AK2 with $50 \mu \mathrm{M}$ tyrphostin B42 (Fig. 3C). However, when FSDC were treated with GM-CSF or TNF- $\alpha$ for 15,30 , or $60 \mathrm{~min}$, no accumulation of p65 in the nuclei of the cells was observed (data not shown).

\section{DISCUSSION}

In the present work, we show that LPS, TNF- $\alpha$, and GM-CSF increase the expression of iNOS in a skinderived dendritic cell line (FSDC) by a mechanism involving the activation of J AK2, thereby leading to the production of NO. Moreover, in these cells, the activation of J AK 2 is crucial for the translocation of NF-kB to the nucleus upon activation with LPS.

We found that LPS was more potent than TNF- $\alpha$ or GM-CSF in activating $\mathrm{NO}_{2}^{-}$production due to stimulation of iNOS expression. In contrast to the significant effect of LPS, TNF $-\alpha$, and GM-CSF on the $\mathrm{NO}_{2}^{-}$production by FSDC, no effect of IL-1 $\beta$ was observed (Fig. 1) despite the fact that these cells express IL-1 receptors (unpublished observations). LPS was also recently shown to stimulate the production of cytokines by human peripheral blood DC (33). Therefore, LPS may cause NO production both directly and indirectly via the synthesis of cytokines that also stimulate NO production. Accordingly, other authors have shown that iNOS expression can be induced by LPS and IFN- $\gamma$ in bone marrow DC and LC $(20,31)$, in contrast to thelack of effect of IFN- $\gamma$ plus LPS on the expression of iNOS mRNA in mouse epidermal LC (4). We observed that a subpopulation of the FSDC did not show increased expression of iNOS upon stimulation with LPS or GM-CSF, as determined by immunocytochemistry (Fig.
2). We do not know why a low percentage of cells express iNOS even in the presence of LPS and GM-CSF. However, our results are in agreement with those obtained in highly purified bone marrow DC stimulated with IF N- $\gamma$ plus LPS (20).

The intracellular signaling events involved in iNOS expression are not well understood, and the knowledge of the mechanisms involved in the control of $\mathrm{NO}$ synthesis by different cell types is a subject of current interest. It was shown that PKC, PTKs, and CAMP are important regulators of iNOS gene expression $(23,28$, $30)$, but the expression of iNOS appears to be regulated in a cell-specific manner $(14,23,28-30)$.

We observed that genistein inhibited the LPS- and GM-CSF-induced $\mathrm{NO}_{2}^{-}$production, which indicates that activation of tyrosine kinase pathways is involved in the regulation of iNOS induction in FSDC. These findings are in agreement with observations in other cell types showing that genistein suppresses the expression of iNOS activity induced by cytokines $(23,29)$. In contrast, genistein had no effect on $\mathrm{NO}_{2}^{-}$production induced by TNF $-\alpha$ (Table 2).

The JAK2 inhibitor tyrphostin B42 was a potent antagonist of the GM-CSF-induced $\mathrm{NO}_{2}^{-}$production, although SB-203580 also inhibited the $\mathrm{NO}_{2}^{-}$production induced by GM-CSF (Table 2). Recent studies indicate that GM-CSF induces the activation of the MAPK pathway (2), J NK (18), and J AK2 $(35,39)$. However, in agreement with our results, J AK2 seems also to be a primary kinase regulating all of the known GM-CSF signals, as previously reported in BA/F 3 cells (35). Moreover, the JAK2 protein kinase is necessary for binding and phosphorylation of the GM-CSF receptor BC chain in CV-1 cells (39). These observations can explain the potent effect of tyrphostin B42 in the GM-CSF-induced NO production by FSDC. To our knowledge, the present study provides the first evidence for the signaling pathways involved in the NO production induced by GM-CSF.

Our results also indicate that the p38 MAPK is involved in iNOS expression by TNF- $\alpha$ in FSDC. Other authors reported the involvement of the p38 MAPK in 

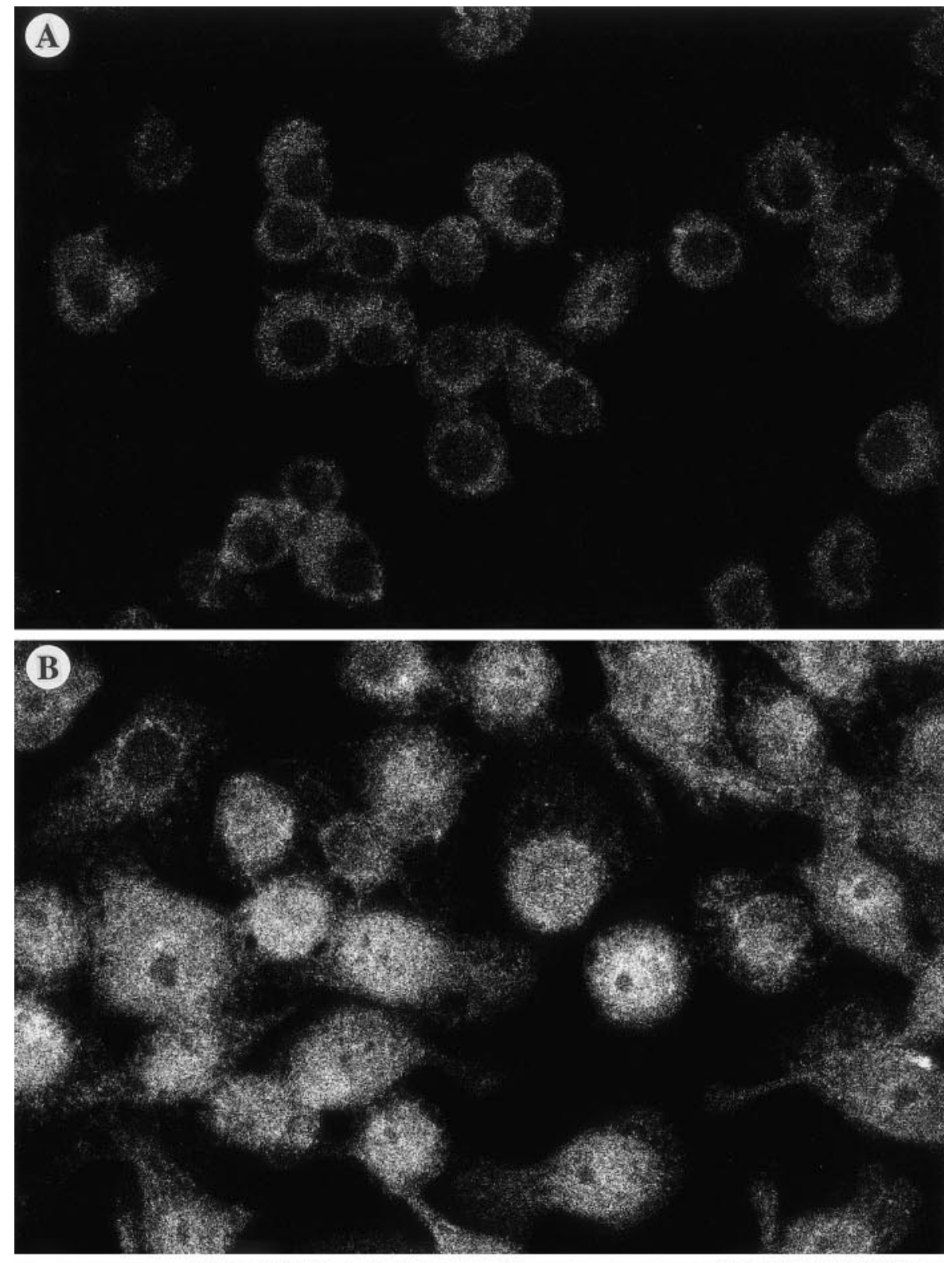

Fig. 3. Translocation of p65 into the nuclei of FSDC in response to LPS. FSDC were maintained in culture medium (A), treated with 5 $\mu \mathrm{g} / \mathrm{ml}$ LPS for $30 \mathrm{~min}(\mathrm{~B})$, or preincubated with $50 \mu \mathrm{M}$ tyrphostin B42 for $2 \mathrm{~h}$ before stimulation with $5 \mu \mathrm{g} / \mathrm{ml}$ LPS for $30 \mathrm{~min}$ (C) Cells were then fixed and incubated with antibody against p65 followed by FITC-conjugated anti-rabbit immunoglobulins as de scribed in MATERIALS AND METHODS. Intracellular localization of FITC-labeled p65 was observed using a confocal fluorescent microscope (magnification $\times 300$ ).

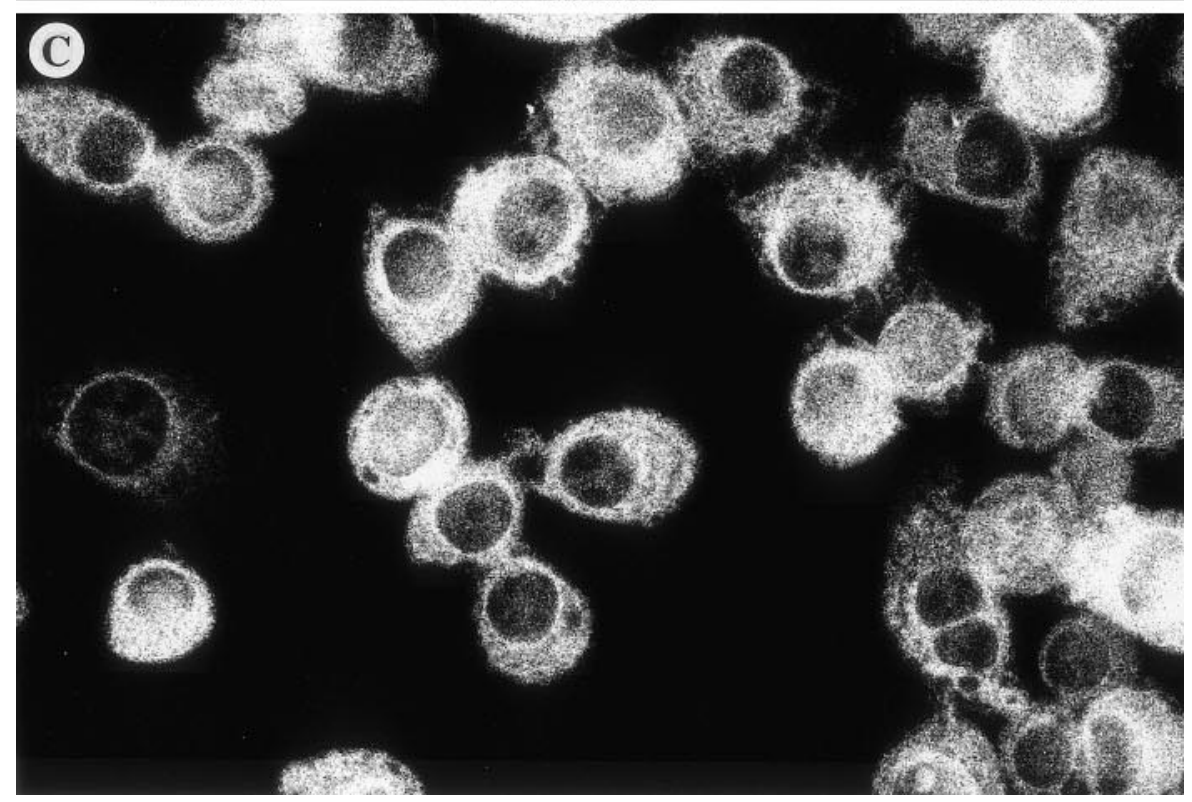


the signaling pathways of TNF- $\alpha$. The TNF- $\alpha$-stimulated phosphorylation and activation of cytosolic phospholipase $A_{2}$ are completely abolished in neutrophils treated with SB-203580 (36). The p38 MAPK activity is also required for the transcriptional induction of iNOS by TNF- $\alpha$ and IL- $1 \alpha$ in astrocytes (6), but, in serumstarved mesangial cells, the inhibition of p38 MAPK promoted IL-1 $\beta$-induced iNOS expression and subsequent NO production (12). The most likely explanation for these seemingly inconsistent results is that the complex regulation of iNOS expression is tissuespecific.

The MEK inhibitor PD-098059 also inhibited NO production induced by TNF - $\alpha$ in FSDC (Table2). TNF- $\alpha$ increased ERK 1 and ERK 2 phosphorylation in IEC-6 cells, and PD-098059 inhibited TNF- $\alpha$-induced IEC-6 cell growth (7). In contrast, in mouse astrocytes, iN OS expression induced by TNF- $\alpha$ and IL- $1 \alpha$ was only partially affected by PD-098059 (6). However, our results suggest that both GM-CSF and TNF- $\alpha$ induce $\mathrm{NO}_{2}^{-}$production mainly through the JAK signaling pathway (Table 2). Accordingly, the activation of iNOS expression in DLD-1 cells seems to require J AK activity, especially the IF N- $\gamma$-activated J AK2 (15).

The lack of effect of PD-098059 on $\mathrm{NO}_{2}^{-}$production induced by LPS rendered the involvement of the p42/ p44 MAPK pathway in iNOS production induced by LPS unlikely. Accordingly, in glial cells, expression of iNOS stimulated by IFN- $\gamma /$ LPS has been reported to require tyrosine kinase activity, specifically J AK2 (27), and the Ras/MAPK signaling pathway does not appear to beinvolved in the I FN- $\gamma / \mathrm{LPS}$-evoked iNOS induction (26). Our results also indicated that the JAK2 is involved in the NO production induced by LPS, since tyrphostin B42 was a potent antagonist of the LPSinduced $\mathrm{NO}_{2}^{-}$production in FSDC (Table 2). The p38 MAPK is also involved in the $\mathrm{NO}_{2}^{-}$production induced by LPS in these cells, although to a much lower extent.

The other subgroup of MAPK, the JNK, may also play a role in the signaling pathway leading to an increase in NO production in FSDC, but this possibility was not investigated in this work, since there are no specific inhibitors available.

Another important aspect is the cross talk and signal integration among MAPK pathways and among MAPK pathways and other signaling pathways. Our results demonstrated that p38 MAPK and MEK cooperate in the NO production induced by LPS and cytokines (Table 2). It is also possible that the MAPK and the AK signaling pathways cooperate in FSDC to trigger the NO production induced by LPS, GM-CSF, and TNF- $\alpha$. In fact, in HCD-57 cells, a significant contribution of the cytosolic tyrosine kinase J AK2 to the erythropoietininduced activation of the Ras/MEK cascade was observed (3).

Activation of the NF-kB was shown to represent a crucial step in the induction of iNOS (38). In FSDC we demonstrated that LPS, but not TNF- $\alpha$ or GM-CSF, induced the translocation of $\mathrm{NF}-\kappa \mathrm{B}$ into the nucleus (Fig. 3) by a mechanism that involves the J AK2, since the specific inhibitor of this kinase, tyrphostin B42, completely prevented the translocation of $\mathrm{NF}-\kappa \mathrm{B}$ after LPS stimulation. To our knowledge, this is the first report showing the involvement of J AK 2 in the NF-kB activation. Taken together, our results indicate that, although J AK2 participates in the induction of iNOS by LPS and cytokines in FSDC, this kinase is coupled to the activation of $\mathrm{NF}-\mathrm{kB}$ only in response to stimulation with LPS. Although the p38 MAPK played a minor role in the stimulation of NO production evoked by LPS, the antagonist SB-203580 was without effect on the translocation of NF-kB to the nucleus in the same experimental conditions, suggesting that the effect of p38 MAPK in the expression of iNOS is not mediated via NF-kB activation.

It is clear that JAKs serve to phosphorylate the signal transducer and activator of transcription (STATs) when the cytokine receptor lacks intrinsic kinase activity. Activated STATs form dimers, translocate to the nucleus, and bind to response elements to induce transcription (13). Therefore, it is possible that, in FSDC, the NF-kB is not the only transcription factor involved in the induction of iNOS by LPS and cytokines.

There are potentially significant physiological and physiopathological aspects of iNOS expression and NO production by DC. NO appears to be involved in skin physiology, growth, and remodeling (5). Because it is diffusible across cells, NO produced by LC regulates lymphocyte prol iferation by inhibiting or inducing apoptosis $(9,20)$. Therefore, elucidation of the molecular mechanisms by which endotoxin and cytokine induce NO production by DC is of major importance and may have implications for the design and execution of immunotherapeutic strategies.

We thank Dr. G. Girolomoni (Laboratory of I mmunology, I stituto Dermopatico dell'I mmacolata, I stituto di Ricovero e Cura a Carattere Scientifico, Rome, Italy) for the kind gift of the fetal skin-derived dendritic cell line. We thank Dr. J . Reis for technical assistance in the utilization of the fluorescent confocal microscope.

This work was supported by Praxis/P/SAU/126/96.

Address for reprint requests and other correspondence: $M$. C. Lopes, F aculdade de Farmácia da Universidade de Coimbra, Rua do Norte, 3000 Coimbra Codex, Portugal.

Received 21 December 1998; accepted in final form 9 August 1999.

\section{REFERENCES}

1. Akiyama, T., and H. Ogawara. Use and specificity of genistein as inhibitor of protein tyrosine kinases. Methods Enzymol. 201: 362-370, 1991.

2. Bittorf, T., R. J aster, and J . Brock. Rapid activation of the MAP kinase pathway in hematopoietic cells by erythropoietin, granulocyte-macrophage col ony-stimulating factor and interleukin-3. Cell. Signal. 6: 305-311, 1994.

3. Bittorf, T., R. J aster, B. Lüdtke, B. Kamper, and J . Brock. Requirement for J AK 2 in erythropoietin-induced signaling pathways. Cell. Signal. 9: 85- 89, 1997.

4. Blank, C., C. Bogdan, C. Bauer, K. Erb, and H. Moll. Murine epidermal Langerhans cells do not express inducible nitric oxide synthase. Eur. J . I mmunol. 26: 792- 796, 1996.

5. Bruch-Gerharz, D., T. Ruzicka, and V. Kolb-Bachofen. Nitric oxide in human skin: current status and future prospects. J . Invest. Dermatol. 110: 1-7, 1998.

6. Da Silva, J., B. Pierrat, J. L. Mary, and W. Lesslauer. Blockade of p38 mitogen-activated protein kinase pathway inhib- 
its inducible nitric-oxide synthase expression in mouse astrocytes. J . Biol. Chem. 272: 28373-28380, 1997.

7. Dionne, S., I. D. D'Agata, F. M. Ruemmele, E. Levy, J . St.-Louis, A. K. Srivastava, D. Levesque, and E. G. Seidman. Tyrosine kinase and MAPK inhibition of TNF- $\alpha$ and EGFstimulated IEC-6 cell growth. Biochem. Biophys. Res. Commun. 242: 146-150, 1998.

8. Dudley, D. T., L. Pang, S. J . Decker, A. J . Bridges, and A. R. Saltiel. A synthetic inhibitor of the mitogen-activated protein kinase cascade. Proc. Natl. Acad. Sci. USA 92: 7686-7689, 1995.

9. Genaro, A. M., S. Hortelano, A. Alvarez, C. Martínez-A, and L. Boscá. Splenic B lymphocyte programmed cell death is prevented by nitric oxide release through mechanisms involving sustained BCl-2 levels. J . Clin. Invest. 95: 1884- 1890, 1995.

10. Girolomoni, G., M. B. Lutz, S. Pastore, C. U. Abmann, A. Cavani, and P. Ricciardi-Castagnoli. Establishment of a cell line with features of early dendritic cell precursors from fetal mouse skin. Eur. J . I mmunol. 25: 2163-2169, 1995.

11. Green, L. C., D. A. Wagner, J . Glogowski, P. L. Skipper, J . S. Wishnok, and S. R. Tannenbaum. Analysis of nitrate, nitrite, and $\left[{ }^{15} \mathrm{~N}\right]$ nitrate in biological fluids. Anal. Biochem. 126: 131138, 1982

12. Guan, Z., L. D. Baier, and A. R. Morrison. p38 Mitogenactivated protein kinase down-regulates nitric oxide and upregulates prostaglandin $\mathrm{E}_{2}$ biosynthesis stimulated by interleukin-1ß. J . Biol. Chem. 272: 8083-8089, 1997.

13. Horvath, C. M., and J . E. Darnell, J r. The state of the STATS: recent developments in the study of signal transduction to the nucleus. Curr. Opin. Cell Biol. 9: 233-239, 1997.

14. J oly, G. A., M. Ayres, and R. G. Kilbourn. Potent inhibition of inducible nitric oxide synthase by geldanamycin, a tyrosine kinase inhibitor, in endothelial, smooth muscle cells, and in rat aorta. FEBS Lett. 403: 40-44, 1997.

15. Kleinert., H., T. Waallerath, G. Fritz, I. Ihrig-Biedert, F. Rodriguez-Pascual, D. A. Geller, and U. Förstermann. Cytokine induction of NO synthase II in human DLD-1 cells: roles of the J AK-STAT, AP-1 and NF-кB signaling pathways. Br. J . Pharmacol. 125: 193-201, 1998.

16. Knowles, R. G., and S. Moncada. Nitric oxide synthase in mammals. Biochem. J . 298: 249-258, 1994.

17. Kunz, D., H. Mühl, w. Gaby, and J . Pfeilschifter. Two distinct signalling pathways trigger the expression of inducible nitric oxide synthase in rat mesangial cells. Proc. Natl. Acad. Sci. USA 91: 5387-5391, 1994.

18. Liu, R., T. Itoh, K. Arai, and S. Watanabe. Activation of c-J un $\mathrm{N}$-terminal kinase by human granulocyte macrophage-colony stimulating factor in BA/F 3 cells. Biochem. Biophys. Res. Commun. 234: 611-615, 1997.

19. Lockhart, B. P., K. C. Cressey, and J . M. Lepagnol. Supression of nitric oxide formation by tyrosine kinases inhibitors in murine N9 microglia. Br. J . Pharmacol . 123: 879- 889, 1998.

20. Lu, L., C. A. Bonham, F. G. Chambers, S. C. Watkins, R. A. Hoffman, R. L. Simmons, and A. W. Thomson. Induction of nitric oxide synthase in mouse dendritic cells by IF N- $\gamma$, endotoxin, and interaction with allogeneic $T$ cells. Nitric oxide production is associated with dendritic cell apoptosis. J . Immunol. 157: 3577-3586, 1996.

21. Me $\beta$ mer, U. K., and B. Brüne. Modification of macrophage glyceral dehyde-3-phosphatedehydrogenase in response to nitric oxide. Eur. J . Pharmacol. 302: 171-182, 1996.

22. Meydan, N., T. Grunberger, H. Dadi, M. Shahar, E. Arpaia, Z. Lapidot, J . S. Leeder, M. Freedman, A. Cohen, A. Gazit, A. Levitzki, and C. M. Roifman. Inhibition of acutelymphoblastic leukaemia by a J AK2 inhibitor. Nature 379: 645- 648, 1996.
23. Miller, D. R.,J . M. Collier, and R. E. Billings. Protein tyrosine kinase activity regulates nitric oxide synthase induction in rat hepatocytes. Am. J . Physiol 272 (Gastrointest. Liver Physiol. 35): G207-G214, 1997.

24. Mosmann, T. Rapid colorimetric assay for cellular growth and survival: application to proliferation and cytotoxicity assays. J . I mmunol. Methods 65: 55-63, 1983.

25. Neary, J . T. MAPK cascades in cell growth and death. News Physiol. Sci. 12: 286-293, 1997.

26. Nishiya, T., T. Uehara, H. E damatsu, Y. Kaziro, H. Itoh, and Y. Nomura. Activation of STAT1 and subsequent transcription of inducible nitric oxide synthase gene in C6 glioma cells is independent of interferon- $\gamma$-induced MAPK activation that is mediated by p21 $1^{\text {ras. }}$ FEBS Lett. 408: 33-38, 1997.

27. Nishiya, T., T. Uehara, and Y. Nomura. Herbimycin A suppresses NF-kB activation and tyrosine phosphorylation of J AK2 and the subsequent induction of nitric oxide synthase in C6 glioma cells. FEBS Lett. 371: 333-336, 1995.

28. Oddis, C. V., R. L. Simmons, B. G. Hattler, and M. S. Finkel. Protein kinase $A$ activation is required for IL-1-induced nitric oxide production by cardiac myocytes. Am. J . Physiol. 271 (Cell Physiol. 40): C429-C434, 1996.

29. Okuda, S., F. Kanda, Y. Kawahara, and K. Chihara. Regulation of inducible nitric oxide synthase expression in L6 rat skeletal muscle cells. Am. J. Physiol. 272 (Cell Physiol. 41): C35-C40, 1997.

30. Paul, A., K. Doherty, and R. Plevin. Differential regulation by protein kinase $\mathrm{C}$ isoforms of nitric oxide synthase induction in RAW 264.7 macrophages and rat aortic smooth muscle cells. Br. J . Pharmacol. 120: 940-946, 1997.

31. Qureshi, A. A., J . Hosoi, S. Xu, A. Takashima, R. D. Granstein, and E. A. Lerner. Langerhans cells express inducible nitric oxide synthase and produce nitric oxide. J . Invest. Dermatol. 107: 815-821, 1996.

32. Sarih, M., V. Souvannavong, and A. Adam. Nitric oxide synthase induces macrophage death by apoptosis. Biochem. Biophys. Res. Commun. 191: 503- 508, 1993.

33. Verhasselt, V., C. Buelens, F. Willems, D. D. Groote, N. Haeffner-Cavaillon, and M. Goldman. Bacterial lipopolysaccharide stimulates the production of cytokines and the expression of costimulatory molecules by human peripheral blood dendritic cells. Evidence for a soluble CD14-dependent pathway. J . Immunol . 158: 2919-2925, 1997.

34. Wallach, D. Cell death induction by TNF: a matter of self control. Trends Biochem. Sci. 22: 107-109, 1997.

35. Watanabe, S., T. Itoh, and K. Arai. Roles of J AK kinases in human GM-CSF receptor signal transduction. J. Allergy Clin. I mmunol. 98: S183-S191, 1996.

36. Waterman, W. H., T. F. P. Molski, C. Huang, J . L . Adams, and R. I. Sha'afi. Tumor necrosis factor- $\alpha$-induced phosphorylation and activation of cytosolic phospholipase $A_{2}$ are abrogated by an inhibitor of the p38 mitogen-activated protein kinase cascade in human neutrophils. Biochem. J. 319: 17-20, 1996.

37. Wolf, D. J ., and A. Lubeskie. Aminoguanidine is an isoformselective, mechanism-based inactivator of nitric oxide synthase. Arch. Biochem. Biophys. 316: 290- 301, 1995.

38. Xie, Q., Y. Kashiwabara, and C. Nathan. Role of transcription factor NF-kB/Rel in induction of nitric oxide synthase. J. Biol. Chem. 269: 4705-4708, 1994.

39. Zhao, Y., F. Wagner, S. J. Frank, and A. S. Kraft. The amino-terminal portion of the J AK2 protein kinase is necessary for binding and phosphorylation of the granulocyte-macrophage colony-stimulating factor receptor $\beta_{c}$ chain. J. Biol. Chem. 270: 13814-13818, 1995. 